\title{
PENERAPAN METODE PEMBELAJARAN PEER TEACHING UNTUK MENINGKATKAN PRESTASI BELAJAR SISWA SMK PADA KOMPETENSI DASAR MENGGUNAKAN ALAT UKUR
}

\author{
Galih T. Lesmana ${ }^{1}$, Ono Wiharna ${ }^{2}$, Sulaeman ${ }^{3}$ \\ Departemen Pendidikan Teknik Mesin \\ Universitas Pendidikan Indonesia \\ Jl. Dr. Setiabudhi No. 207 Bandung 40154 \\ biohazard_40@yahoo.co.id
}

\begin{abstract}
ABSTRAK
Tujuan penelitian ini adalah untuk mengetahui seberapa besar peningkatan prestasi belajar siswa setelah menggunakan metode pembelajaran peer teaching dan metode pembelajaran klasikal pada kompetensi dasar menggunakan alat ukur. Penelitian ini dilakukan dengan menggunakan metode quasi experiment dengan desain non-equivalent control group design. Populasi dalam penelitian ini adalah siswa kelas X SMKN 1 Lemahsugih teknik kendaraan ringan yang berjumlah 3 kelas dengan jumlah siswa sebanyak 92 orang. Sampel penelitian diambil dua kelas yaitu kelas eksperimen yang menggunakan metode pembelajaran peer teaching dan kelas kontrol menggunakan metode pembelajaran klasikal. Penarikan sampling dalam penelitian ini menggunakan simple random sampling dimana sampel diambil secara acak tanpa memperhatikan strata di dalam populasi itu. Instrumen yang digunakan pada penelitian ini berupa soal pre test dan soal pre test. Hasil penelitian diperoleh rata-rata prestasi belajar siswa pada skor post test setelah menggunakan metode pembelajaran peer teaching sebesar 24,85 dan rata-rata prestasi belajar siswa pada skor post test setelah menggunakan metode pembelajaran klasikal sebesar 21,85. Peningkatan prestasi belajar siswa ( $N$-Gain) kelompok eksperimen yang menggunakan metode pembelajaran peer teaching sebesar 0,61 yang termasuk pada kategori sedang, sedangkan peningkatan prestasi belajar siswa $(N$-Gain) kelompok kontrol yang menggunakan metode pembelajaran klasikal sebesar 0,39 yang termasuk pada kategori sedang.
\end{abstract}

Kata kunci: peer teaching, prestasi belajar, alat ukur, kompetensi.

\section{PENDAHULUAN}

Proses pendidikan pada umumnya dilakukan disuatu lembaga yang disebut sekolah. Sekolah terdiri dari beberapa jenjang, dimulai dari TK/SD sampai perguruan tinggi. Penulis akan membahas tentang SMK yang mana SMK merupakan lembaga yang mempersiapkan lulusannya untuk memasuki dunia kerja dan mempunyai kemampuan serta mempunyai prestasi belajar yang baik. Prestasi belajar siswa salah satunya dapat dipengaruhi oleh metode pembelajaran yang digunakan oleh guru dalam proses belajar mengajar. Setiap guru hendaknya menentukan metode pembelajaran yang paling sesuai dengan kompetensi yang hendak disampaikan. Guru harus mampu memilih metode pembelajaran yang dianggap paling efektif serta memiliki kemampuan tentang penggunaan berbagai metode atau mengkombinasikan beberapa metode yang relevan. Faktor metode pembelajaran mempunyai

\footnotetext{
${ }^{1}$ Mahasiswa Departemen Pendidikan Teknik Mesin FPTK UPI

${ }^{2}$ Dosen Departemen Pendidikan Teknik Mesin FPTK UPI

${ }^{3}$ Dosen Departemen Pendidikan Teknik Mesin FPTK UPI
} 
peran yang besar dalam usaha mencapai tujuan pembelajaran, termasuk pembelajaran pada mata pelajaran produktif pada kompetensi dasar menggunakan alat-alat ukur.

Menggunakan alat-alat ukur adalah salah satu kompetensi dasar produktif siswa kelas X SMKN 1 Lemahsugih. Sesuai dengan kurikulum yang diterapkan di SMKN 1 Lemahsugih bahwa dalam pembelajaran mata pelajaran produktif dalam hal ini kompetensi dasar menggunakan alat-alat ukur bahwa siswa dikatakan telah kompeten atau lulus apabila mendapat nilai Kriteria Kelulusan Minimal (KKM $\geq 70)$.

Kenyataanya, menurut data yang didapat dari guru kompetensi dasar menggunakan alatalat ukur menunjukan bahwa siswa yang mendapatkan nilai di bawah 70 jumlahnya masih cukup banyak yaitu sebesar 32\%. Hasil ini dimungkinkan terdapat ketidaksesuaian atau kesalahan dalam proses pembelajaran yang berlangsung. Ketidaksesuaian tersebut bisa disebabkan oleh faktor guru ataupun faktor siswa.

Faktor guru, khususnya metode pembelajaran yang diterapkan mungkin belum sesuai dengan kondisi siswa. Hal ini dapat menjadi salah satu penyebab rendahnya prestasi belajar yang diperoleh siswa. Metode adalah cara yang digunakan untuk mengimplementasikan rencana yang sudah disusun dalam kegiatan nyata agar tujuan yang telah disusun tercapai secara optimal (Sanjaya, 2006). Guru hendaknya memperhatikan keadaan siswa maupun lingkungan sebelum menentukan metode yang akan digunakan sehingga tujuan pembelajaran dapat tercapai secara optimal.

Faktor siswa, khususnya keaktifan siswa dalam proses pembelajaran masih kurang. Keaktifan siswa dalam proses pembelajaran sangat penting, apabila siswa aktif maka proses pembelajaran tidak monoton karena proses belajar mengajar tidak berjalan satu arah. Salah satu kurangnya keaktifan siswa dalam proses pembelajaran adalah enggan bertanya pada saat ada materi yang disampaikan guru tidak dimengerti. Penyebabnya bisa disebabkan karena siswa tersebut malu ataupun canggung untuk bertanya pada gurunya.

Salah satu penyebab kurangnya keaktifan siswa bisa disebabkan karena siswa malu bertanya kepada guru tentang kesulitan dalam proses pembelajaran. Masalah tersebut dapat diatasi dengan menerapkan metode yang memungkinkan siswa dapat menyampaikan masalah yang dialaminya tanpa rasa malu maupun canggung, salah satunya dengan menerapkan metode pembelajaran peer teaching. Metode peer teaching memungkinkan guru meminta bantuan kepada anak yang lebih pintar untuk menerangkan materi kepada temannya.

Adakalanya seorang siswa lebih mudah menerima keterangan yang diberikan oleh kawan sebangku atau kawan yang lain karena tidak adanya rasa enggan atau malu untuk 
bertanya (Arikunto, 2012). Guru dapat meminta bantuan kepada anak-anak yang menerangkan kepada kawan-kawannya. Pelaksanaan ini disebut Peer Teaching (Tutor Sebaya) karena mempunyai usia yang hampir sebaya.

Metode pembelajaran peer teaching adalah pembelajaran yang terpusat pada siswa, dalam hal ini siswa belajar dari siswa lain yang memiliki status umur, kematangan/harga diri yang tidak jauh berbeda dari dirinya sendiri. Sehingga anak tidak merasa begitu terpaksa untuk menerima ide-ide dan sikap dari "gurunya" yang tidak lain adalah teman sebayanya itu sendiri. Bantuan belajar oleh teman sebaya dapat menghilangkan kecanggungan. Penjelasan teman sebaya lebih mudah dipahami, selain itu dengan teman sebaya tidak ada rasa enggan, rendah diri, malu, dan sebagainya, sehingga diharapkan siswa yang kurang paham tidak segan-segan untuk mengungkapkan kesulitan-kesulitan yang dihadapinya.

Metode peer teaching tidak hanya berguna bagi siswa yang enggan bertanya atau kurang aktif, tapi juga untuk siswa yang dijadikan tutor bagi temannya. Salah satu tanda bahwa seseorang telah menguasai suatu materi adalah dia bisa mengajarkannya kembali pada orang lain. Beberapa pakar meyakini bahwa suatu subyek dapat dikatakan benar-benar dikuasai hanya jika pembelajar mampu mengajarkannya kepada orang lain. Mengajar teman (peer teaching) memberikan kesempatan kepada siswa untuk mempelajari sesuatu dengan sebaik-baiknya dan pada saat yang bersamaan menjadi sumber belajar bagi satu sama lain (Silberman, 2013).

Siswa dikatakan menguasai atau memahami pelajaran apabila siswa tersebut mampu mengajarkannya kepada orang lain. Metode pembelajaran peer teaching siswa diberikan kesempatan untuk mempelajari pelajaran dan disaat bersamaan dapat menjadi sumber belajar bagi temannya. Oleh karena itu, suasana belajar akan lebih hidup dan siswa akan lebih aktif karena siswa menjadi saling berinteraksi.

\section{METODE PENELITIAN}

Metode yang digunakan dalam penelitian ini adalah metode kuasi eksperimen (quasi exsperimental design). Selama melakukan eksperimen, siswa merupakan objek penelitian yang tetap mengikuti pelajaran dalam kelas seperti biasa. Selain itu, pemilihan objek penelitian juga tidak dilakukan secara acak. Desain penelitian yang digunakan dalam penelitian ini adalah (nonequivalent control group design). Desain ini menempatkan subjek penelitian ke dalam dua kelompok kelas yang terdiri dari kelompok eksperimen dan kelompok kontrol yang tidak dipilih secara acak. 


\section{HASIL PENELITIAN}

Instrumen yang baik biasanya dilakukan uji coba sebelum digunakan. Uji coba instrumen ini diikuti 27 orang siswa kelas X TKR A SMKN 1 Lemahsugih tahun ajaran 2015/2016. Instrumen penelitian yang diuji coba berupa tes ujian berbentuk pilihan ganda yang berjumlah 40 soal. Uji coba instrumen tersebut meliputi uji validitas, uji reliabilitas, daya pembeda dan tingkat kesukaran butir soal. Tujuan uji coba di atas adalah untuk melihat item soal mana saja yang dapat digunakan maupun dihilangkan. Uji coba validitas dilakukan dengan membandingkan $t_{\text {hitung }}$ dengan $t_{\text {tabel }}$, dari uji coba tersebut diperoleh 10 butir soal yang tidak valid yaitu soal nomor 2,6,13,19,23,29,30,31,35, dan 40. Item soal tersebut tidak digunakan kembali dalam instrumen karena soal yang valid yaitu sebanyak 30 soal sudah mewakili semua indikator yang ada.

Tahap selanjutnya setelah dilakukan uji validitas adalah dilakukan uji realibilitas yang menggunakan rumus Spearman-Brown. Berdasarkan hasil analisis uji realibilitas didapatkan nilai koefisien reliabilitas sebesar 0,52 yang tergolong pada realibilitas sedang. Tahap berikutnya dilakukan uji tingkat kesukaran yang kemudian didapatkan hasil yang menunjukkan terdapat 7 buah soal yang termasuk kategori mudah, 29 buah soal termasuk kategori sedang, dan 4 soal yang termasuk pada kategori sukar.

Tahap berikutnya dilakukan analisis daya pembeda yang menunjukkan bahwa terdapat 5 butir soal yang termasuk pada kategori baik sekali, 22 butir soal termasuk pada kategori baik, 6 butir soal termasuk pada kategori cukup, dan 7 butir soal termasuk pada kategori jelek. Setelah melakukan uji instrumen berdasarkan urutan yang telah disebutkan di atas, maka instrumen soal yang digunakan untuk penelitian berjumlah 30 butir soal yang telah mewakili dari setiap indikator.

Data prestasi belajar sebagai parameter penelitian diambil dari dua kelas sampel, yaitu kelompok eksperimen dan kelompok kontrol yang masing-masing diambil sampel 26 siswa. Data skor pre test didapatkan dari hasil tes siswa dari siswa pada kelompok eksperimen dan kelas kontrol sebelum diberikan perlakuan atau proses pembelajaran dengan cara membagikan soal pilihan ganda yang berjumlah 30 soal. Rata-rata skor awal kelas eksperimen lebih tinggi daripada kelas kontrol. Skor rata-rata siswa pada kelas eksperimen yaitu sebesar 16,92 lebih tinggi apabila dibandingkan dengan skor rata-rata kelas kontrol yaitu sebesar 16,46 .

Data skor post test didapatkan dari hasil test siswa dari kelompok kontrol dan eksperimen sesudah dilakukan perlakuan atau proses pembelajaran sehingga nantinya dapat 
diketahui seberapa besar peningkatan prestasi belajar siswa yang ditandai dengan peningkatan skor yang didapatkan siswa. Soal post test ini menggunakan soal yang digunakan pada soal post test, hanya urutan soalnya saja yang dibedakan. Rata-rata kemampuan siswa dalam mengerjakan soal pada kelas eksperimen lebih tinggi daripada kelas kontrol. Rata-rata skor yang didapatkan kelas eksperimen adalah sebesar 24,85, sedangkan kelas kontrol sebesar 21,85 .

Uji homogenitas digunakan untuk mengetahui homogen atau tidaknya data kedua sampel. Data yang digunakan dalam uji homogenitas adalah data pretest dari kelas eksperimen dan kelas kontrol. Hasil uji homogenitas didapatkan data $F_{\text {hitung }}=1,19$. Nilai tersebut lebih kecil dari nilai $\mathrm{F}_{\text {tabel }}=1,94$ yang terletak pada kondisi homogen, dengan demikian dapat diartikan bahwa data dari kedua sampel penelitian tersebut adalah homogen. Berdasarkan data tersebut, maka eksperimen dapat dilakukan pada kedua kelas tersebut.

Uji normalitas data bertujuan untuk menguji apakah data yang diuji itu berdistribusi normal atau tidak. Kondisi dan berdistribusi normal menjadi syarat untuk menguji hipotesis menggunakan statistik parametrik. Uji normalitas skor gain ini ditentukan dengan menggunakan uji kecocokan chi-kuadrat. Uji normalitas prestasi belajar (gain) untuk kelompok eksperimen diperoleh $X^{2}{ }_{\text {hitung }}=4,92$. Nilai ini berada pada $P$-value $=0,0811$ untuk $\mathrm{dk}=\mathrm{k}-3$, dikarenakan $P$-value $=0,0811>\alpha=0,05$ terletak pada penerimaan normal yang artinya kondisi data gain kelompok eksperimen berdistribusi normal pada taraf signifikansi $8,11 \%$. Kelompok kontrol memperoleh nilai $x_{\text {hitung }}^{2}=3,52$. Nilai ini berada pada $P$-value $=$ 0,067 untuk $\mathrm{dk}=\mathrm{k}-3$, dikarenakan $P$-value $=0,067>\alpha=0,05$ terletak pada penerimaan normal yang artinya kondisi gain kelompok kontrol berdistribusi normal pada taraf signifikansi $6,7 \%$.

Data gain ternormalisasi diperoleh dari data rata-rata pre test dan post test pada kelas eksperimen maupun kelas kontrol. Rata-rata gain normalisasi kelas eksperimen adalah 0,61. Nilai tersebut termasuk pada kriteria sedang, sehingga $N$-gain yang dihasilkan termasuk kategori sedang, sedangkan rata-rata gain normalisasi kelas kontrol adalah 0,39. Nilai tersebut termasuk pada kriteria sedang, sehingga $N$-gain yang dihasilkan termasuk kategori sedang.

Uji hipotesis penelitian berdasarkan pada peningkatan prestasi belajar siswa, yaitu selisih nilai pretest dan posttest. Nilai $\mathrm{t}_{\text {hitung }} 4,97$, untuk $\mathrm{dk}=50$, diperoleh $\mathrm{t}_{\text {tabel }}=1,67$. Karena $t_{\text {hitung }}>\mathrm{t}_{\text {tabel }}$, maka $\mathrm{H}_{\mathrm{o}}$ ditolak dan $\mathrm{H}_{\mathrm{A}}$ diterima, yang artinya bahwa peningkatan prestasi belajar siswa yang menggunakan metode peer teaching lebih baik dibandingkan prestasi belajar menggunakan metode klasikal. Peningkatan prestasi belajar siswa yang menggunakan 
metode pembelajaran peer teaching tidak lebih tinggi dibandingkan dengan siswa yang menggunakan metode pembelajaran klasikal. Peningkatan prestasi belajar siswa yang menggunakan metode pembelajaran peer teaching lebih tinggi dibandingkan dengan siswa yang menggunakan metode pembelajaran klasikal.

\section{PEMBAHASAN}

Prestasi belajar siswa setelah menggunakan metode pembelajaran peer teaching lebih tinggi apabila dibandingkan dengan prestasi belajar siswa dengan menggunakan metode pembelajaran klasikal. Hal ini disebabkan karena metode peer teaching dapat membantu siswa yang kurang aktif menjadi lebih aktif dalam proses pembelajaran sehingga dapat membantu siswa tersebut dalam memahami pelajaran sehingga dapat meningkatkan prestasi belajar. Salah satu indikator seseorang sudah cukup menguasai suatu materi adalah ketika seseorang tersebut mampu menerangkan atau mengajarkannya pada orang lain. Beberapa pakar meyakini bahwa suatu subyek dapat dikatakan benar-benar dikuasai hanya jika pembelajar mampu mengajarkannya kepada orang lain (Silberman, 2013). Berdasarkan beberapa penjelasan tersebut, metode peer teaching memiliki beberapa aspek yang dapat membantu meningkatkan prestasi belajar siswa.

Berdasarkan temuan pada proses penelitian yang telah dilakukan proses pembelajaran menggunakan metode klasikal dalam hal ini metode ceramah, sebagian siswa kurang aktif dalam proses pembelajaran. Penggunaan metode ceramah yang terlalu lama akan membuat siswa cepat bosan dan tidak bersemangat dalam mengikuti proses pembelajaran (Ormrod, 2008). Hal ini dapat mempengaruhi prestasi prestasi belajar siswa yang terlihat dari hasil $\mathrm{N}$ Gain siswa yang mendapatkan 0,39 yang mana lebih rendah apabila dibandingkan dengan metode peer teaching.

Metode pembelajaran ceramah dapat dikatakan adalah metode satu arah yang berpusat pada guru, sehingga metode ini menjadikan guru lebih aktif dalam proses pembelajaran. Standar kompetensi menggunakan alat ukur membutuhkan proses praktik agar siswa dapat terjun langsung untuk menambah pengalaman dalam belajar.

Prestasi belajar siswa yang menggunakan metode peer teaching lebih besar daripada prestasi belajar siswa yang menggunakan metode klasikal. Hal ini dapat dilihat dari perolehan $\mathrm{N}$-Gain yang didapatkan pada kelas eksperimen yang menggunakan metode peer teaching dan kontrol yang menggunakan metode klasikal yang meskipun keduanya termasuk pada kategori sedang. Namun jumlah $N$-Gain kelas eksperimen lebih besar yaitu sebesar 0,61 sedangkan 
kelas kontrol sebesar 0,39. Pada beberapa kasus, bimbingan teman (peer tutoring) menghasilkan pencapaian akademik yang lebih besar dibandingkan entah pembelajaran tuntas ataupun pengajaran seisi kelas yang lebih tradisional. Salah satu kemungkinan alasannya adalah peer teaching memberikan siswa lebih banyak kesempatan untuk membuat respon aktif yang dari sudut pandang behavioris sangat penting bagi pembelajaran. Peer teaching menyediakan suatu konteks di dalamnya siswa yang mengalami kesulitan mungkin lebih nyaman dalam mengajukan pertanyaan ketika mereka tidak memahami pelajaran sehingga prestasi belajar pun dapat meningkat (Djamarah, 2014).

\section{KESIMPULAN}

Kesimpulan penelitian ini, yaitu: rata-rata prestasi belajar siswa pada kelas yang menggunakan metode peer teaching berkategori sedang. Penggunaan metode pembelajaran peer teaching pada kelas eksperimen memberikan pengaruh yang lebih tinggi terhadap prestasi belajar siswa pada kompetensi dasar menggunakan alat ukur. Pernyataan tersebut dapat dilihat dari perolehan rata-rata $N$-gain pada kelas eksperimen sebesar 0,61.

\section{DAFTAR PUSTAKA}

Arikunto, S. (2012). Pengelolaan Kelas dan Siswa. Jakarta: Rajawali.

Djamarah, S.B \& Zain, A. (2014). Strategi Belajar Mengajar. Jakarta: Rineka Cipta.

Ormrod, J. E. (2008). Psikologi Pendidikan, Membantu Siswa Tumbuh dan Berkembang. Jakarta: Erlangga.

Sanjaya, W. (2006). Strategi Pembelajaran Berorientasi Standar Proses Pendidikan. Jakarta: Kencana.

Silbeman, M. L. (2013). Pembelajaran Aktif, 101 Strategi Untuk Mengajar Secara Aktif. Jakarta: PT. Indeks. 